\title{
Jerzy Kostorz, Zdzisław Pytka, Piotr Bechta (red.). Katechizm dla średnio zaawansowanych. Opole: Wydawnictwo Świętego Krzyża, 2021
}

DOI: http://dx.doi.org/10.12775/PCh.2021.015

Diecezja opolska posiada duże tradycje w rozpowszechnianiu użytecznych i wartościowych katechizmów, pomocy do nauczania religii oraz śpiewników i modlitewników (por. bp Antoni Adamiuk, Mały katechizm, ok. 60 wydań oraz Droga do nieba, również ok. 60 wydań). Zbliżający się złoty jubileusz diecezji (2023 r.) jest okazją, by kontynuować i rozwijać dobre tradycje. Niewątpliwie w ten nurt wpisuje się Katechizm dla średnio zaawansowanych pod redakcją ks. prof. UO Jerzego Kostorza, Zdzisława Pytki i Piotra Bechty. Katechizm łączy stare z nowym, jak ewangeliczny gospodarz domu, który ,ze swego skarbca wyjmuje to, co nowe i stare” (Mt 13, 52). Nowy jest kontekst społeczno-religijny, nowe wyzwania ewangelizacyjno-katechetyczne oraz potrzeba dotarcia właśnie do owych ,średnio zaawansowanych”, którzy może i przez jakiś czas chodzili na lekcje religii, ale niewiele zapamiętali i nie utrwalili swojej wiary. Stara jest natomiast forma - katechizm z pytaniami.

Benedykt XVI w motu proprio wydanym w celu zatwierdzenia i opublikowania Kompendium Katechizmu Kościoła Katolickiego pisał:

Kompendium, z uwagi na swoją zwięzłość, jasność i integralność, adresowane jest także do tych, którzy żyjąc w świecie nieuporządkowanym i pod wpływem różnorodnych przekazów, pragną poznać Drogę Życia, Prawdę powierzoną przez Boga Kościołowi przez Jego Syna.

Z kolei we wprowadzeniu dodał, że:

kompendium zachowuje formę dialogową, która nawiązuje do starego katechetycznego rodzaju literackiego, posługującego się pytaniami i odpowiedziami. Chodzi o zaproponowanie idealnego dialogu między nauczycielem i uczniem za pośrednictwem przynaglającej sekwencji pytań, które wciągają czytelnika, zapraszając go do odkrywania ciągle nowych aspektów prawd swojej wiary. Forma dialogowa sprzyja także znacznemu skróceniu tekstu, redukując go do rzeczy istotnych. Może sprzyjać przyswojeniu i ewentualnej memoryzacji treści (20 marca 2005 r.). 
Myślę, że powyższe metodologiczne założenia były też u podstaw omawianej pomocy katechetycznej: zwięzłość, jasność i integralność, forma dialogowa (pytanie - odpowiedź) oraz krótki tekst, możliwy do zapamiętania.

Nowy katechizm opolski składa się z trzech części i aneksu. Pierwsza część, zatytułowana „Nasza wiara”, zawiera konieczną syntezę wyznawanej wiary (10 jednostek). Część druga, zatytułowana „Nasz Kościół”, przedstawia istotne elementy życia wspólnoty wiary - Kościoła (10 jednostek). Część trzecia, zatytułowana „Życie chrześcijańskie”, przywołuje to, co ludzie ochrzczeni winni ujawniać w swoim postępowaniu i w swych etycznych wyborach - wierność wobec wyznawanej i praktykowanej wiary. Zamykający całość aneks zawiera cenną pomoc praktyczną: mały katechizm, najważniejsze modlitwy, obrzędy sakramentu chrztu, sakramentu bierzmowania, sakramentu małżeństwa i namaszczenia chorych.

Powyższe dodatki ujawniają poniekąd adresatów Katechizmu dla średnio zaawansowanych. Autorzy wyjaśniają to we wprowadzeniu: kim są ,,średnio zaawansowani"? Zamiarem autorów katechizmu było „stworzenie takiego kompendium, które ma posłużyć jako narzędzie duszpasterskie przede wszystkim wobec tych, którzy z różnych powodów zrezygnowali z systematycznej lekcji religii w szkole, a mimo to pragną przystąpić do sakramentu bierzmowania czy małżeństwa”. Ale nie tylko: „Katechizm może też służyć jako pomoc w formacji rodziców i rodziców chrzestnych przed sakramentem chrztu dziecka, może też być narzędziem do stałego pogłębienia wiedzy religijnej, a w konsekwencji wiary" (s. 7-8). Bardzo szeroki krąg adresatów. Można zgodzić się z tym, że odbiorcami katechizmu mają być poszukujący, którzy zarzucili systematyczną katechizację, ale „mimo to pragną” przygotować się i przyjąc sakramenty św., lecz „narzędziem do stałego pogłębienia wiedzy religijnej, a w konsekwencji wiary” musi być „coś więcej”, np. Pismo Święte i Katechizm Kościoła katolickiego. Zapewne Katechizm dla średnio zaawansowanych może spełnić rolę zachęty (parenezy) czy pozytywnej ,prowokacji” do dalszych kroków na drodze do stałego pogłębiania wiedzy religijnej i wychowania w wierze.

Atutem nowej pomocy katechetycznej czy raczej pre-ewangelizacyjnej jest coś, co Biblia i Tradycja nazywały simplex dives, czyli bogactwem prostoty (por. 2 Kor 8, 2). Mistrz z Nazaretu - pierwszy i doskonały Ewangelizator (zob. Dokument Papieskiego Komitetu Obchodów Jubileuszowego Roku 2000, Jezus Chrystus, jedyny Zbawiciel świata, wczoraj, dziś i na wieki, Katowice 1997, s. 33) - do thumów mówił w przypowieściach, a na osobności wyjaśniał ich znaczenie wybranej grupie uczniów (por. Mk 4, 11). Adresatami omawianego katechizmu będą przede wszystkim ci, którzy są na początku 
drogi deutero-katechumenalnej, jak to ujął autor Listu do Hebrajczyków, „ponownie potrzebujecie pouczenia o podstawowych zasadach nauki Bożej. Zamiast stałego pokarmu, znów potrzebujecie mleka" (Hbr 5, 12). Katechizm ma więc

[przypomnieć] im podstawowe elementy wiary, [inspirować] w rzeczywistym procesie nawrócenia, [pogłębić] w nich prawdę i wartość orędzia chrześcijańskiego wobec zastrzeżeń teoretycznych i praktycznych, [pomóc] im w wyborze i przeżywaniu Ewangelii w życiu codziennym, [uzdolnić] ich do uzasadnienia nadziei, jaka jest w nich, [dodać] odwagi do realizacji ich powołania misyjnego... (Dyrektorium ogólne o katechizacji, nr 194).

Jeśli udałoby się dzięki tej pomocy zrealizować tych kilka celów i zadań tzw. katechezy ewangelizacyjnej, to spełniłaby ona swoje wzniosłe cele i zadania. Ale to wymaga współpracy nauczyciela i ucznia, katechety i katechizowanego, a przede wszystkim dobrej woli i łaski Bożej.

Katechizm ma jeszcze jedną tzw. „wartość dodaną” - to „bogata prostota" edytorska. W dobie rozbudowanej i krzykliwej grafiki, proponowanych pomocy i podręczników, Katechizm dla średnio zaawansowanych cechuje wręcz asceza w tym względzie. Szata graficzna w opracowaniu Michała Grochoła jest czytelna i komunikatywna, budzi nadzieję (kolor zielony). Warto też na koniec wyróżnić zadania, które autorzy katechizmu proponują jako formę aktywizacji z wykorzystaniem najnowszych środków społecznego przekazu.

Jan Kochel*

ORCID: 0000-0002-0399-6056

Opole, Polska

* Ks. prof. dr hab. Jan Kochel, Katedra Teologii Pastoralnej, Katechetyki, Pedagogiki i Psychologii, Instytut Nauk Teologicznych, Uniwersytet Opolski, email: jkochel@uni.opole.pl. 